Article

\title{
Actual and Reference Evapotranspiration in a Cornfield in the Zhangye Oasis, Northwestern China
}

\author{
Lianglei Gu ${ }^{1, *(\mathbb{D})}$, Zeyong $\mathrm{Hu}^{1}{ }^{1}$, Jimin Yao ${ }^{2}$ (D) and Genhou Sun ${ }^{1}$ \\ 1 Key Laboratory of Land Surface Process and Climate Change in Cold and Arid Regions (LPCC)/Nagqu \\ Station of Plateau Climate and Environment (NPCE), Cold and Arid Regions Environmental and \\ Engineering Research Institute, Chinese Academy of Sciences, Lanzhou 730000, China; \\ zyhu@lzb.ac.cn (Z.H.); genhou.sun@gmail.com (G.S.) \\ 2 State Key Laboratory of Cryospheric Science (SKLCS)/Cryosphere Research Station on Qinghai-Xizang \\ Plateau (CRS), Cold and Arid Regions Environmental and Engineering Research Institute, Chinese Academy \\ of Sciences, Lanzhou 730000, China; yjm@lzb.ac.cn \\ * Correspondence: gull@lzb.ac.cn; Tel.: +86-931-496-7654
}

Received: 28 April 2017; Accepted: 3 July 2017; Published: 8 July 2017

\begin{abstract}
Evapotranspiration (ET) is an important component of the surface energy balance and water cycle, especially in arid and semiarid regions. The characteristics of the actual evapotranspiration $\left(E T_{a}\right)$, which was calculated using the eddy covariance method, and the reference evapotranspiration $\left(E T_{0}\right)$, which was estimated using the Food and Agriculture Organisation (FAO) Penman-Monteith method, were analysed. This work focussed on the seasonal variations in evapotranspiration and crop coefficient $\left(K_{c}\right)$ above the heterogeneous canopy of an arid oasis ecosystem in a cornfield of the Zhangye oasis in northwestern China. The results showed that in 2008, the total net radiation $\left(R_{n}\right)$ was $2457.73 \mathrm{MJ} \cdot \mathrm{m}^{-2}$ and that the rainfall was $117 \mathrm{~mm}$. The average wind velocity, air temperature, and specific humidity, which were observed $2 \mathrm{~m}$ above the ground surface, were $1.23 \mathrm{~m} \cdot \mathrm{s}^{-1}, 7.07^{\circ} \mathrm{C}$, and $3.66 \mathrm{~g} \cdot \mathrm{kg}^{-1}$, respectively. The total $E T_{a}$ and $E T_{0}$ were $654.69 \mathrm{~mm}$ and $1039.92 \mathrm{~mm}$, respectively; thus, the $E T_{0}$ was higher than the $E T_{a}$. The difference between the $E T_{0}$ and $E T_{a}$ was high in summer and autumn, and low in winter and spring. The $E T_{a}$ was greatly influenced by irrigation events, whereas the $E T_{0}$ was not influenced by irrigation. The $E T_{a}$ and $E T_{0}$ were both greatly influenced by meteorological elements. The $K_{c}$ values were less than 0.5 outside of the maize-growing stage and greater than 0.5 during the entire maize-growing stage (from 20 April to 22 September 2008). The $K_{c}$ values were $0.63,0.75,0.78,0.76,0.61$ and 0.71 at the seedling, shooting, heading, filling, and maturity stages and the entire growth stage, respectively.
\end{abstract}

Keywords: actual evapotranspiration; reference evapotranspiration; crop coefficient $K_{c}$; eddy covariance method; FAO Penman-Monteith method; Zhangye oasis; Heihe river basin

\section{Introduction}

Evapotranspiration $(E T)$ is important for water resource management, hydrometeorological forecasting, environmental conservation, and agricultural competitiveness [1-3]. ET is an indicator for the rate of change in the global water cycle, and it is a necessary variable for most numerical weather forecasting and global climate model simulations [2,4-6]. ET can represent a substantial portion of the regional water budget depending on the water availability, climate regime, and landscape conditions [2,7]. ET is a dominant controlling factor of climate and hydrology at the local and global scales, and it is also an important factor controlling energy and mass exchange between terrestrial ecosystems and the atmosphere. This issue has received considerable attention [8-12]. 
Many land surface experiments, such as the European Field Experiment in a DesertificationThreatened Area (EFEDA) [13], the Hydrologic Atmospheric Pilot Experiment in the Sahel (HAPEX-Sahel) [14], the Heihe International Field Experiment (HEIFE) [15,16], the Inner-Mongolia Grassland Atmosphere Surface Study (IMGRASS) [17] and the Land-atmosphere Interaction Experiment in an Arid Region of Northwest China (NWC-ALIEX) [18], have been implemented in semiarid and arid regions. Numerous studies have analysed energy and water balances, water resource supply and demand, and water resource security in the irrigation regions of the Heihe River Basin in northwestern China [19-21]. Although ET and spring wheat irrigation in the middle reaches of the Heihe Basin have been previously evaluated [22,23], further investigation is necessary.

The Watershed Airborne Telemetry Experimental Research (WATER) project chose the Zhangye oasis as a key experimental area for an arid region hydrology experiment in the oasis-desert zone of the middle reaches of the Heihe River Basin [24]. The terrain is flat, with elevations ranging from $1500 \mathrm{~m}$ to $2000 \mathrm{~m}$. The Zhangye oasis is located in the inland arid belt of northwestern China. The artificial oasis, the Gobi Desert, and the transitional zones between the oasis and desert are the dominant landscapes [25]. The total area of the Zhangye oasis is $4.19 \times 10^{4} \mathrm{~km}^{2}$, accounting for $32.23 \%$ of the total area in the Heihe River Basin. The vegetation coverage and oasis area accounted for $8.67 \%$ and $9.8 \%$ of the Zhangye oasis total area, respectively [26]. In such regions, ET is high, and the water availability is limited. In recent decades, increasing human activities and associated overexploitation or illogical water resource utilisation in the Zhangye oasis have resulted in a series of environmental problems arising in the lower reaches of the Heihe River Basin. Such problems include land desertification and salinisation as well as natural vegetation degeneration. As a result, environmental degradation has become a research focus in recent decades. An equitable partitioning of water resources among competing shareholders and ecosystems along the Heihe River Basin has been hampered by a lack of accurate water budgets, particularly a lack of accurate ET estimates [21].

Since Dalton introduced the ET formula in 1802, and with the development of observations and theories, various methods have been proposed for estimating ET, such as the Bowen ratio-energy balance method, aerodynamic method, eddy covariance (EC) method, Penman-Monteith model, and remote sensing method [1,27-29]. Actual evapotranspiration $\left(E T_{a}\right)$ is one of the key factors in land-atmosphere interactions. Apart from the incoming radiation, $E T_{a}$ is the most important component of the energy budget at the ground surface with sufficient moisture [30]. Reference evapotranspiration $\left(E T_{0}\right)$ is the basis for estimating crop evapotranspiration $\left(E T_{c}\right)$ and calculating crop irrigation requirements [31,32]. Increased $E T_{0}$ estimation accuracy can result in the conservation of economic and water resources for both the planning and management of irrigated areas $[33,34]$.

The objectives of this study were to estimate the $E T_{a}$ using the eddy covariance method and the $E T_{0}$ using the Food and Agriculture Organisation (FAO) Penman-Monteith method over a cornfield in the Zhangye oasis region, and to analyse the seasonal variations in the $E T_{a}$ and $E T_{0}$. The meteorological conditions and crop coefficients were also analysed.

\section{Materials and Methods}

\subsection{Experimental Site and Instrumentation}

The Yingke site $\left(100.41^{\circ} \mathrm{E}, 38.86^{\circ} \mathrm{N}\right.$, and $1519 \mathrm{~m}$ in elevation) was chosen as the study site to measure the $E T_{a}$ and $E T_{0}$ over a cornfield in the Zhangye oasis in the middle reaches of the Heihe River Basin, the second largest inland river basin in the arid region of northwestern China. The site was built for the WATER experiment project in November 2007 (Figure 1a). In the cornfield (Figure 1b,c), the male and female parents of FL-2 maize were sown on 20 and 28 April 2008, respectively, at $60 \mathrm{~cm}$ row spacing, with a distance of $25 \mathrm{~cm}$ between plants. 


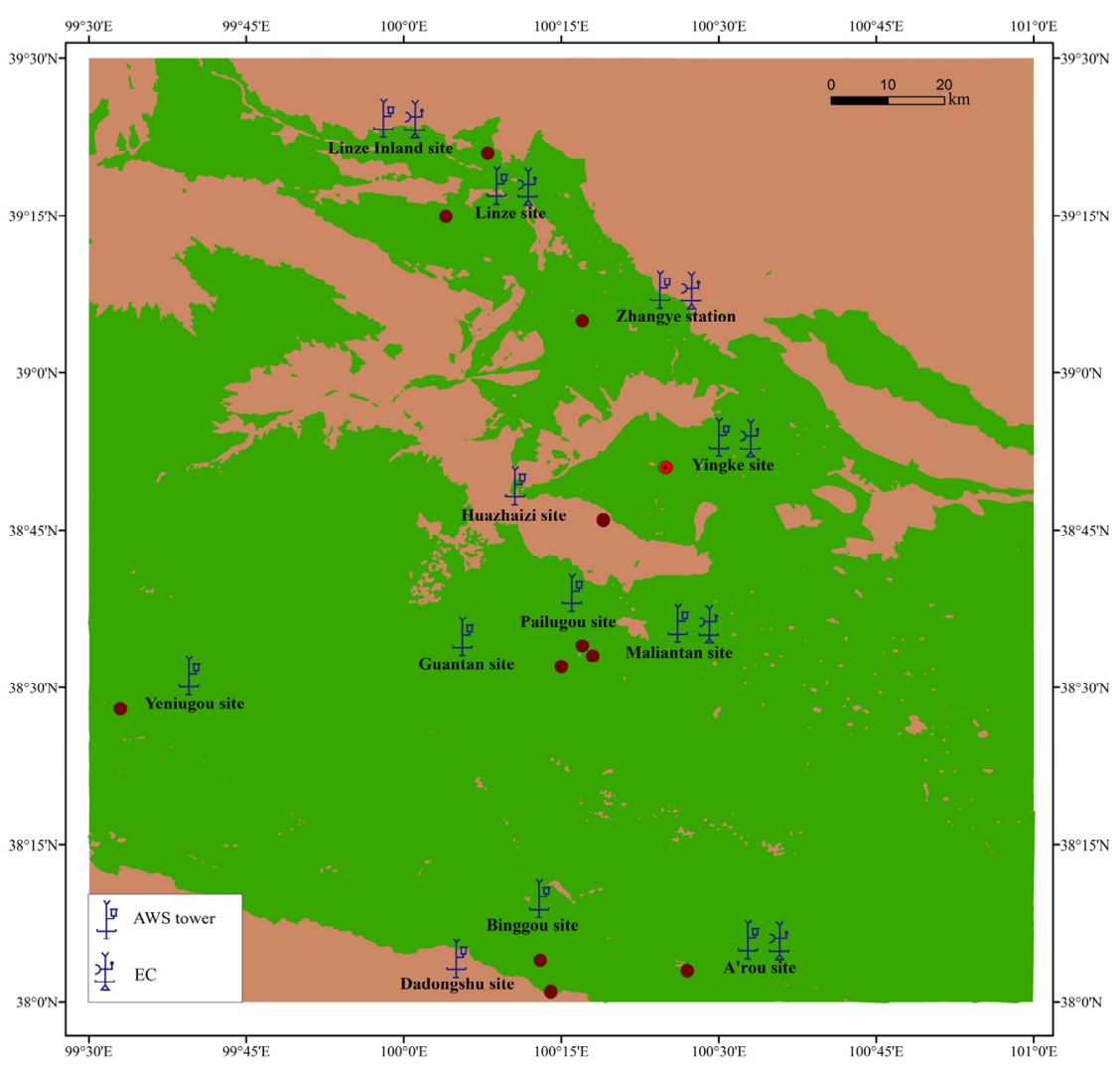

(a)

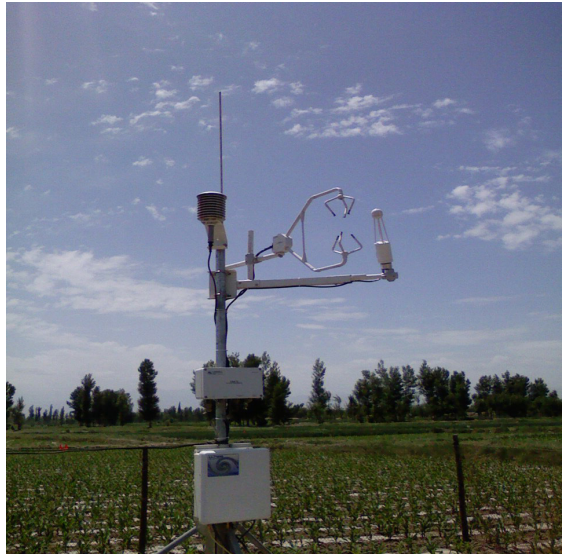

(b)

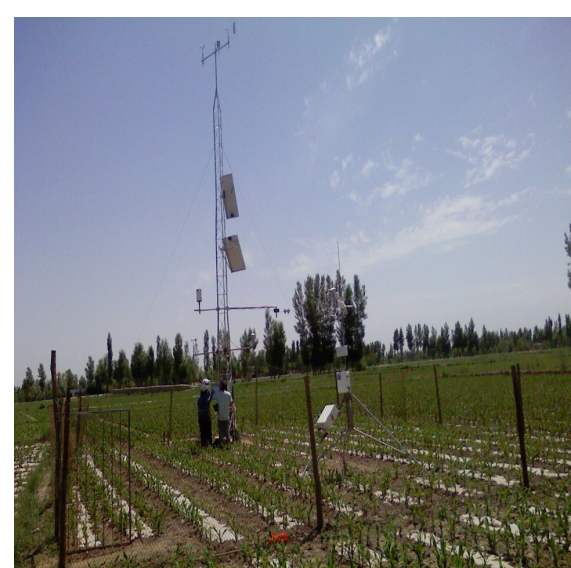

(c)

Figure 1. The Watershed Airborne Telemetry Experimental Research (WATER) experiment observation site locations (a), the eddy covariance (EC) system (b), and the automatic weather station tower (AWS-Tower) at the Yingke site (c).

The monthly averages of the meteorological parameters observed at the Zhangye meteorological station from 1951 to 2000 are listed in Table 1. These data show that the annual averages of the wind velocity, air temperature and specific humidity were approximately $2.02 \mathrm{~m} \cdot \mathrm{s}^{-1}$, $7.08{ }^{\circ} \mathrm{C}$, and $4.84 \mathrm{~g} \cdot \mathrm{kg}^{-1}$, respectively. The annual rainfall was approximately $70-210 \mathrm{~mm}$, and the pan-measured annual evaporation was approximately $1500-2300 \mathrm{~mm}$. The ET was substantially higher than the rainfall. The region is arid, and the local rainfall is inadequate for crop growth. Thus, irrigation is a major source of soil moisture for agricultural production. 
Table 1. Monthly averages of the meteorological elements observed at the Zhangye meteorological station from 1951 to 2000 .

\begin{tabular}{|c|c|c|c|c|c|}
\hline Date & $\begin{array}{l}\text { Wind Velocity } \\
\left(\mathrm{m} \cdot \mathrm{s}^{-1}\right)\end{array}$ & $\begin{array}{c}\text { Air Temperature } \\
\left({ }^{\circ} \mathrm{C}\right)\end{array}$ & $\begin{array}{l}\text { Specific Humidity } \\
\left(\mathrm{g} \cdot \mathrm{kg}^{-1}\right)\end{array}$ & $\begin{array}{l}\text { Evaporation } \\
\left(\mathrm{mm} \cdot \text { Day }^{-1}\right)\end{array}$ & $\begin{array}{c}\text { Rainfall } \\
\left(\mathrm{mm} \cdot \text { Day }^{-1}\right)\end{array}$ \\
\hline January. & 1.70 & -9.84 & 1.16 & 1.16 & 0.06 \\
\hline February & 1.95 & -5.63 & 1.40 & 2.08 & 0.05 \\
\hline March & 2.44 & 2.01 & 2.31 & 4.48 & 0.13 \\
\hline April & 2.78 & 9.62 & 3.49 & 8.09 & 0.18 \\
\hline May & 2.53 & 15.50 & 5.53 & 9.62 & 0.49 \\
\hline June & 2.11 & 19.41 & 8.38 & 9.60 & 0.88 \\
\hline July & 1.98 & 21.46 & 10.47 & 9.19 & 1.17 \\
\hline August & 1.92 & 20.31 & 9.94 & 8.45 & 1.20 \\
\hline September & 1.70 & 14.52 & 7.21 & 6.26 & 0.62 \\
\hline October & 1.65 & 6.83 & 4.26 & 4.09 & 0.18 \\
\hline November & 1.79 & -1.28 & 2.45 & 1.97 & 0.07 \\
\hline December & 1.64 & -7.92 & 1.48 & 1.12 & 0.05 \\
\hline
\end{tabular}

The EC system (Figure 1b) and an automatic weather station tower (AWS-Tower) system (Figure 1c) were used during the observation period. The EC included a three-dimensional ultrasonic anemometer (CSAT3, Campbell Scientific, Inc., Logan, UT, USA) used to measure the wind velocity component and temperature fluctuations, an open-path infrared gas analyser (Li-7500, Li-COR Inc., Lincoln, NE, USA) used to measure the $\mathrm{H}_{2} \mathrm{O}$ and $\mathrm{CO}_{2}$ concentration, and a data logger (CR5000, Campbell Scientific, Inc., Logan, UT, USA) used to log the observation data continuously at a rate of $10 \mathrm{~Hz}$. The AWS-Tower measured the wind velocity (010C, Vaisala Inc., Helsinki, Finland), air temperature, relative humidity (HMP45C, Vaisala Inc., Helsinki, Finland) at heights of 2 and $10 \mathrm{~m}$, air pressure (CS100, Campbell Scientific, Inc., Logan, UT, USA), rainfall (52202, R.M. Young, Traverse, MI, USA), radiation budget (CM3/CG3, Campbell Scientific, Inc., Logan, UT, USA), soil temperature (109, Campbell Scientific, Inc., Edmonton, AB, Canada), soil moisture content (CS616, Campbell Scientific, Inc., Edmonton, AB, Canada) at depths of 10, 20, 40, 80, 120, and $160 \mathrm{~cm}$, and soil heat flux (HFP01SC, Radiation and Energy Balance Systems, Seattle, WA, USA) at depths of 5 and $15 \mathrm{~cm}$. The measurements were calculated continuously from 10-min averages. In this study, the data from November 2007 to January 2009 were analysed, and the time was based on Beijing local time.

\subsection{Actual Evapotranspiration Estimates}

In this study, actual evapotranspiration $\left(E T_{a}\right)$ values were mainly obtained by the eddy covariance (EC) method, which is considered an advanced technique for accurately capturing $E T$ information over short-term periods (e.g., $10 \mathrm{~min}$ ) in a large area [25]. The EC method does not include assumptions concerning the required eddy diffusivities. Disadvantages of the EC method include dew formation on the instruments during daybreak, which renders the instruments unreliable, and reduced instrument reliability during precipitation events [34]. EC system monitoring was occasionally interrupted during the observation period because of instrument failure and / or severe climatic conditions, and the missing data were filled in using meteorological data via the aerodynamic method, which is a conventional method for calculating the $E T_{a}[35]$.

\subsubsection{Eddy Covariance (EC) Method}

The EC technique measures turbulent fluxes according to the fluctuations around each block mean signal [36]. Corrections were performed for the data monitored by the EC system using a double coordinate rotation $(D R)$ for each half hour [37]. $D R$ corrections were widely used to process the data obtained through the EC system because of the convenience and accuracy of the technique. The $D R$ corrections forced the mean horizontal wind direction to the $\mathrm{X}$-direction and the mean vertical 
and lateral wind vectors to zero [38]. After the corrections, the $E T_{a}$ was calculated according to the following equations:

$$
\begin{gathered}
E T_{a}=\frac{L E \cdot s}{L_{v} \cdot \rho} \\
L E=\rho L_{v} \overline{w^{\prime} q_{v}^{\prime}} \\
L_{v}=2.5 \times 10^{6}-2323 \times t
\end{gathered}
$$

where $L E$ is the latent heat flux $\left(\mathrm{w} \cdot \mathrm{m}^{-2}\right) ; s$ is the time (s); $\rho$ is the air density $\left(\mathrm{kg} \cdot \mathrm{m}^{-3}\right) ; L_{v}$ is the latent heat of vaporization $\left(\mathrm{J} \cdot \mathrm{kg}^{-1}\right) ; w$ is the vertical velocity $\left(\mathrm{m} \cdot \mathrm{s}^{-1}\right) ; q_{v}$ is the specific humidity $\left(\mathrm{g} \cdot \mathrm{kg}^{-1}\right)$; and $t$ is the air temperature $\left({ }^{\circ} \mathrm{C}\right)$.

Energy closure is an important criterion used to evaluate the accuracy of the eddy covariance method [39], also for evaluate the accuracy of the evapotranspiration. The energy closure ratio $(C R)$ is defined as follows [40]:

$$
C R=\frac{R n-G_{0}}{H s+L E}
$$

where $R_{n}$ is the net radiation $\left(\mathrm{w} \cdot \mathrm{m}^{-2}\right), G_{0}$ is the ground heat flux $\left(\mathrm{w} \cdot \mathrm{m}^{-2}\right) ; H s$ is the sensible heat flux $\left(\mathrm{w} \cdot \mathrm{m}^{-2}\right)$; and $L E$ is the latent heat flux $\left(\mathrm{w} \cdot \mathrm{m}^{-2}\right)$.

Figure 2 shows the energy closure status in 2008 using the daily average energy flux data at the Yingke site. The $C R$ was 0.81 at the site, consistent with the results (0.82) of Wang et al. [41]. The energy unclosure may reflect the omission of other storage terms of heat in the biomass and air between the measurement height and ground surface, the amount of energy consumed by photosynthesis or released by respiration, and an underestimation of $G_{0}$.

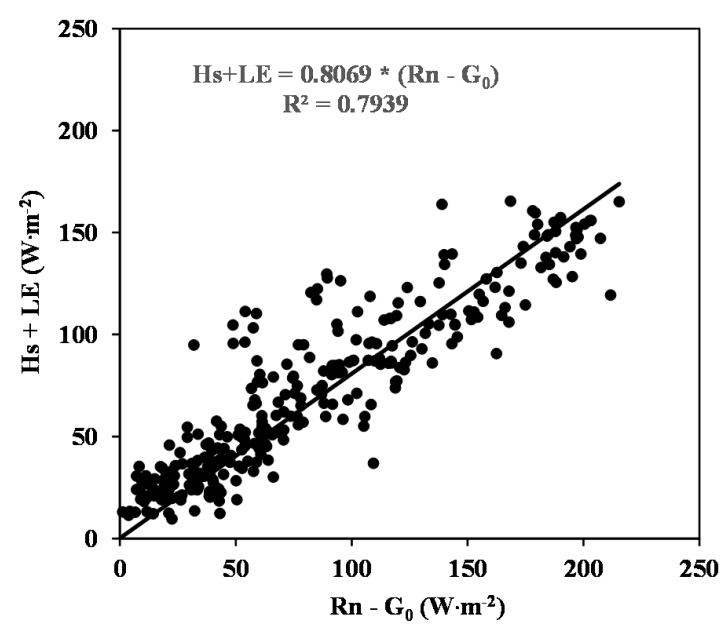

Figure 2. Energy closure status using the daily average energy flux data at the Yingke site.

\subsubsection{Aerodynamic Method}

According to Oke [42], Malek [43] and Monteith and Unsworth [44], the modified aerodynamic equation for calculating the latent heat flux $\left(L E, \mathrm{w} \cdot \mathrm{m}^{-2}\right)$ is expressed as follows:

$$
L E=0.622 \cdot L v \cdot \rho \cdot k^{2} \cdot \frac{\left[e_{a}\left(z_{2}\right)-e_{a}\left(z_{1}\right)\right] \cdot\left[u\left(z_{1}\right)-u\left(z_{2}\right)\right]}{P \cdot\left[\ln \left(\frac{z_{2}-d}{z_{1}-d}\right)\right]^{2}} \cdot\left(\Phi_{M} \cdot \Phi_{V}\right)^{-1}
$$

where $\rho$ is the air density $\left(\mathrm{kg} \cdot \mathrm{m}^{-3}\right) ; k=0.4$ is the von Karman constant; $d$ is the zero displacement height $(\mathrm{m}) ; P$ is the air pressure $(\mathrm{hPa}) ; e_{a}\left(z_{1}\right)$ and $e_{a}\left(z_{2}\right)$ represent the actual vapour pressure (hPa), and $u\left(z_{1}\right)$ and $u\left(z_{2}\right)$ represent the wind velocity $\left(\mathrm{m} \cdot \mathrm{s}^{-1}\right)$ at heights of $z_{1}=2 \mathrm{~m}$ and $z_{2}=10 \mathrm{~m}$, respectively; and $\Phi_{M}$ and $\Phi_{V}$ are stability functions for momentum and water vapour transport, respectively. 
The generalized stability factor $\left.F=\left[\Phi_{M} \cdot \Phi_{V}\right)\right]^{-1}$ can be calculated for the stable atmosphere $\left(R_{i}>0\right)$ as follows:

$$
\Phi_{M}=\Phi_{V}=(1-5 R)^{-1}
$$

and

$$
F=\left(1-5 R_{i}\right)^{2}
$$

For unstable atmospheres $\left(R_{i}<0\right)$, the generalized stability factor can be calculated as follows:

$$
\Phi_{M}^{2}=\Phi_{V}=\left(1-16 R_{i}\right)^{-1 / 2}
$$

and

$$
F=\left(1-16 R_{i}\right)^{3 / 4}
$$

$R_{i}$ is the bulk Richardson number expressed as follows:

$$
R_{i}=\frac{g \cdot\left(\frac{d \theta}{d z}\right)}{T \cdot\left(\frac{d u}{d z}\right)^{2}}
$$

where $g$ is the acceleration because of gravity $\left(\mathrm{m} \cdot \mathrm{s}^{-2}\right) ; T$ is the average air temperature $(\mathrm{K})$ over a height interval of $d z(\mathrm{~m})$; and $\theta$ is the potential temperature $(\mathrm{K}) . R_{i}$ is negative, zero and positive under lapse (unstable) conditions, and neutral under inversion (stable) conditions, respectively.

The $E T_{a}$ was calculated according to Equation (1).

\subsection{Reference Evapotranspiration Estimates: FAO Penman-Monteith Method}

The FAO Penman-Monteith method is recommended as the standard $E T_{0}$ method, and it clearly defines the $E T$ of a hypothetical reference vegetated field [27]. This method provides consistent $E T_{0}$ values in many regions and climates $[32,45,46]$ and has long been accepted worldwide as an accurate estimator of $E T_{0}$ compared with other methods, especially for daily calculations [31,47-50].

$E T_{0}$ was estimated according to the following equations [50]:

$$
\begin{gathered}
E T_{0}=\frac{0.408 \Delta\left(R n-G_{s f c}\right)+\gamma \frac{900}{T+273} u_{2}\left(e_{s}-e_{a}\right)}{\Delta+\gamma\left(1+0.34 u_{2}\right)} \\
e^{0}(T)=0.6108 \exp \left(\frac{17.27 T}{T+237.3}\right) \\
e_{s}=\frac{e^{0}\left(T_{\max }\right)+e^{0}\left(T_{\min }\right)}{2} \\
e_{a}=\frac{e^{0}\left(T_{\max }\right) \frac{R H_{\min }}{100}+e^{0}\left(T_{\min }\right) \frac{R H_{\max }}{100}}{2} \\
\Delta=\frac{4098\left[0.6108 \exp \left(\frac{17.27 T}{T+237.3}\right)\right]}{(T+237.3)^{2}} \\
\gamma=0.665 \times 10^{-3} \mathrm{P}
\end{gathered}
$$

where $E T_{0}$ is the reference evapotranspiration $\left(\mathrm{mm} \cdot \mathrm{d}^{-1}\right) ; R_{n}$ is the net radiation $\left(\mathrm{MJ} \cdot \mathrm{m}^{-2} \cdot \mathrm{d}^{-1}\right) ; G_{s f c}$ is the soil heat flux at the ground surface $\left(\mathrm{MJ} \cdot \mathrm{m}^{-2} \cdot \mathrm{d}^{-1}\right) ; e_{s}$ is the saturation vapour pressure of the air temperature $(\mathrm{KPa}) ; e_{a}$ is the actual vapour pressure $(\mathrm{KPa}) ; \gamma$ represents a psychometric constant $\left(\mathrm{KPa} \cdot{ }^{\circ} \mathrm{C}^{-1}\right) ; T$ and $u$ are the mean daily air temperature $\left({ }^{\circ} \mathrm{C}\right)$ and wind velocity $\left(\mathrm{m} \cdot \mathrm{s}^{-1}\right)$ at a height of $2 \mathrm{~m}$, respectively; $\Delta$ is the slope of the saturation vapour-pressure curve of the air temperature $\left(\mathrm{KPa} \cdot{ }^{\circ} \mathrm{C}^{-1}\right) ; R H$ is the relative humidity; and $P$ is the air pressure $(\mathrm{KPa})$. 


\section{Results and Discussion}

\subsection{Meteorological Conditions}

Figure 3 shows the hourly net radiation $\left(R_{n}\right)$ at the Yingke Site from November 2007 to January 2009; these data reflect the seasonal characteristics of the $R_{n}$. The maximum $R_{n}$ of each season was 649.28 (spring), 777.93 (summer), 663.54 (autumn), and $473.36 \mathrm{w} \cdot \mathrm{m}^{-2}$ (winter). The maximum monthly total $R_{n}$ was $409.90 \mathrm{MJ} \cdot \mathrm{m}^{-2}$ (June 2008), and the minimum monthly total $R_{n}$ was $23.35 \mathrm{MJ} \cdot \mathrm{m}^{-2}$ (December 2008). The total $R_{n}$ was $2547.73 \mathrm{MJ} \cdot \mathrm{m}^{-2}$ in 2008 (Table 2). Temperatures are influenced by the $R_{n}$. The air temperature $\left(T_{a}\right)$ was observed $2 \mathrm{~m}$ above the ground surface, and the annual average value was $7.07^{\circ} \mathrm{C}$ in 2008 . The monthly average $T_{a}$ reached a maximum $\left(20.59^{\circ} \mathrm{C}\right)$ in July and a minimum $\left(-14.03{ }^{\circ} \mathrm{C}\right)$ in January (Table 3). The hourly average $T_{a}$ was below $31^{\circ} \mathrm{C}$ in spring, rose to a maximum of approximately $34^{\circ} \mathrm{C}$ in summer, then fell below $28^{\circ} \mathrm{C}$ in autumn, and descended to a minimum below $22{ }^{\circ} \mathrm{C}$ in winter. Except in January, February and August in 2008, the monthly and annual averages of $T_{a}$ were lower than the values from 1951 to 2000, as shown in Table 1.

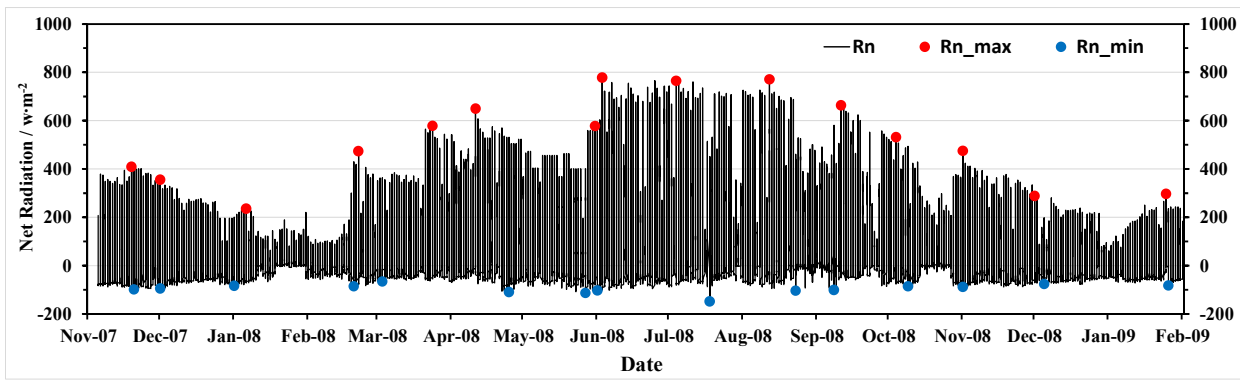

Figure 3. Hourly net radiation $\left(R_{n}\right)$, monthly maximum $\left(R_{n \_ \text {max }}\right)$, and monthly minimum $\left(R_{n \_ \text {min }}\right)$ values of net radiation at the Yingke site from November 2007 to January 2009.

Table 2. Monthly total of the meteorological elements observed at the Yingke site from November 2007 to January 2009.

\begin{tabular}{|c|c|c|c|c|}
\hline Month-Year & $\begin{array}{l}\text { Net Radiation } \\
\left(\mathrm{MJ} \cdot \mathrm{m}^{-2}\right)\end{array}$ & Rainfall (mm) & $\begin{array}{l}\text { Soil Heat Flux a } \\
\quad\left(\mathrm{MJ} \cdot \mathrm{m}^{-2}\right)\end{array}$ & $\begin{array}{l}\text { Soil Heat Flux } \\
\quad\left(\mathrm{MJ} \cdot \mathrm{m}^{-2}\right)\end{array}$ \\
\hline November-2007 & 83.77 & 0.10 & - & -11.71 \\
\hline December-2007 & 32.88 & 0.60 & -5.01 & -18.46 \\
\hline January-2008 & 31.32 & 0.00 & -18.08 & -4.08 \\
\hline February-2008 & 61.99 & 0.10 & -9.53 & -2.77 \\
\hline March-2008 & 217.27 & 0.40 & 16.45 & 11.30 \\
\hline April-2008 & 274.68 & 6.50 & 18.06 & 22.45 \\
\hline May-2008 & 227.97 & 1.10 & 17.41 & 18.21 \\
\hline June-2008 & 409.90 & 13.20 & 5.30 & 3.55 \\
\hline July-2008 & 379.62 & 37.20 & -1.08 & -3.51 \\
\hline August-2008 & 379.70 & 14.10 & -1.94 & - \\
\hline September-2008 & 269.46 & 33.20 & 6.91 & -7.09 \\
\hline October-2008 & 172.61 & 10.50 & -9.69 & -11.71 \\
\hline November-2008 & 99.86 & 0.00 & -10.49 & -13.74 \\
\hline December-2008 & 23.35 & 0.00 & -14.07 & -24.36 \\
\hline January-2009 & 24.51 & 0.10 & -9.88 & -17.15 \\
\hline
\end{tabular}

Notes: ${ }^{a}$ Observed $5 \mathrm{~cm}$ below the ground surface; ${ }^{b}$ Observed $15 \mathrm{~cm}$ below the ground surface.

The monthly average wind velocity observed $2 \mathrm{~m}$ above the ground surface generally ranged between 1.0 and $2.0 \mathrm{~m} \cdot \mathrm{s}^{-1}$ during the observation period (Table 3 ). The maximum hourly average 
wind velocity in 2008 was $9.35 \mathrm{~m} \cdot \mathrm{s}^{-1}$. The average wind velocity in 2008 was $1.23 \mathrm{~m} \cdot \mathrm{s}^{-1}$, which was lower than the average wind velocity from 1951 to 2000, as listed in Table 1.

The monthly average specific humidity observed $2 \mathrm{~m}$ above the ground surface reached a maximum $\left(7.23 \mathrm{~g} \cdot \mathrm{kg}^{-1}\right)$ in July and a minimum $\left(-1.07 \mathrm{~g} \cdot \mathrm{kg}^{-1}\right)$ in January (Table 3). The specific humidity was below $10 \mathrm{~g} \cdot \mathrm{kg}^{-1}$ in spring, rose to a maximum of approximately $20 \mathrm{~g} \cdot \mathrm{kg}^{-1}$ in summer, then fell below $15 \mathrm{~g} \cdot \mathrm{kg}^{-1}$ in autumn and descended to a minimum below $5 \mathrm{~g} \cdot \mathrm{kg}^{-1}$ in winter. The average specific humidity in 2008 was $3.66 \mathrm{~g} \cdot \mathrm{kg}^{-1}$. Except in November and December 2008, the monthly and annual averages of the specific humidity were lower than the average specific humidity from 1951 to 2000 listed in Table 1.

Table 3. Monthly averages of the meteorological elements observed at the Yingke site from November 2007 to January 2009.

\begin{tabular}{|c|c|c|c|}
\hline Month-Year & Air Temperature $*\left({ }^{\circ} \mathrm{C}\right)$ & Wind Velocity $*\left(\mathrm{~m} \cdot \mathrm{s}^{-1}\right)$ & $\begin{array}{c}\text { Specific Humidity * } \\
\left(\mathrm{g} \cdot \mathrm{kg}^{-1}\right)\end{array}$ \\
\hline November-2007 & 0.73 & 1.37 & 2.62 \\
\hline December-2007 & -5.65 & 1.45 & 1.28 \\
\hline January-2008 & -14.03 & 1.23 & 1.06 \\
\hline February-2008 & -9.95 & 1.13 & 1.25 \\
\hline March-2008 & 4.75 & - & 1.87 \\
\hline April-2008 & 10.66 & 1.42 & 2.17 \\
\hline May-2008 & 17.31 & 2.01 & 2.48 \\
\hline June-2008 & 19.87 & 1.46 & 6.33 \\
\hline July-2008 & 20.59 & 1.17 & 9.42 \\
\hline August-2008 & 18.79 & 1.21 & 6.33 \\
\hline September-2008 & 14.40 & 1.00 & 5.78 \\
\hline October-2008 & 9.17 & 1.22 & 3.00 \\
\hline November-2008 & 0.01 & 1.40 & 2.61 \\
\hline December-2008 & -6.77 & 1.45 & 1.59 \\
\hline January-2009 & -9.67 & 1.40 & 1.17 \\
\hline
\end{tabular}

Note: * Observed $2 \mathrm{~m}$ above the ground surface.

Seasonal variations of rainfall are shown in Figure 4. The total rainfall in 2008 was approximately $117 \mathrm{~mm}$, which was lower than the values from 1951 to 2000 (Table 1); the rainfall was concentrated ( $92 \%$ of the annual total) in summer and autumn (June to November 2008). During the observation period, the maximum monthly total rainfall was $37.20 \mathrm{~mm}$ (June 2008, Table 2). Rainfall did not occur in November and December 2008. The seasonal distribution of rainfall was 8.00 (spring), 64.50 (summer), 43.70 (autumn) and $0.70 \mathrm{~mm}$ (winter). The total rainfall was approximately $70 \mathrm{~mm}$ during the entire maize-growing stage (from 20 April to 22 September 2008).

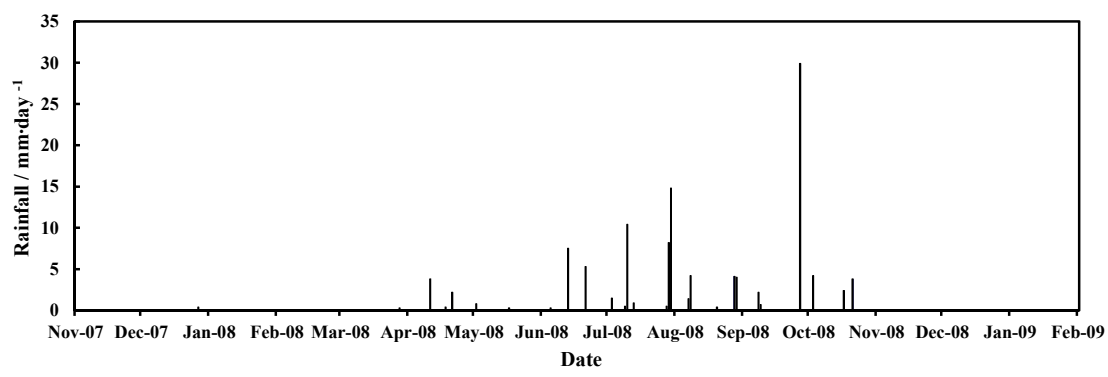

Figure 4. Daily rainfall at the Yingke site from November 2007 to January 2009.

The soil froze in winter, and the underlying land was seasonally frozen ground (Figure 5a). The maximum depth of the frost penetration reached up to approximately $100 \mathrm{~cm}$. The average annual ground surface temperature $\left(T_{g}\right)$ in 2008 was $7.00{ }^{\circ} \mathrm{C}$. The seasonal variations in the soil moisture 
content are shown in Figure 5b. In winter, the soil moisture content was lower because of ground freezing. After March, the ground thawed, and the soil moisture content increased. Extreme soil moisture contents occurred after each irrigation event, which led to the high value centres at $20 \mathrm{~cm}$. Generally, there was a high value belt at a depth of $120 \mathrm{~cm}$. Vertically, the soil moisture content was lowest at $10 \mathrm{~cm}$ and highest at $120 \mathrm{~cm}$ (Table 4). As shown in Figure 5b, the soil moisture content peaked during each irrigation event except for the irrigation event on 25 August, because the soil moisture content data were missing. The monthly total soil heat flux ranged from negative to positive in March, and reached a maximum in May, a trend that was similar to that of the $T_{g}$. The total soil heat flux decreased to negative values again in July (Table 2) due to the oasis "wet island" effect [16,51], which indicates that the high amount of latent heat flux results in a cold land surface and decreases the sensible heat flux and the soil heat flux, even to negative values.

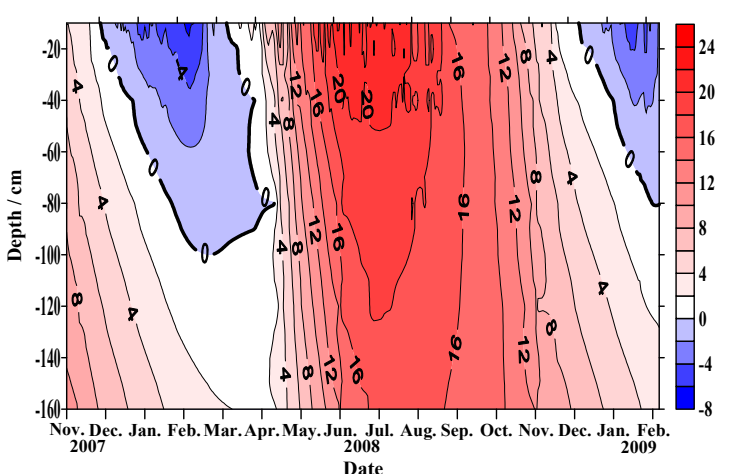

(a)

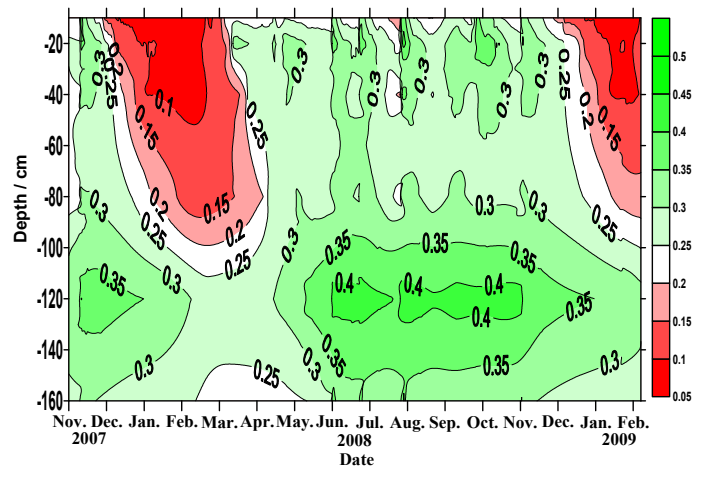

(b)

Figure 5. Seasonal variations in the soil temperatures $\left(\mathbf{a},{ }^{\circ} \mathrm{C}\right)$ and soil moisture content $\left(\mathbf{b}, \mathrm{m}^{3} \cdot \mathrm{m}^{-3}\right)$ at the Yingke site from November 2007 to January 2009.

Table 4. Seasonal average and range in the soil moisture content $\left(\mathrm{m}^{3} \cdot \mathrm{m}^{-3}\right)$ at various depths at the Yingke site from November 2007 to January 2009.

\begin{tabular}{ccccccc}
\hline Soil Depth Season & $\mathbf{1 0} \mathbf{~ c m}$ & $\mathbf{2 0} \mathbf{~ c m}$ & $\mathbf{4 0} \mathbf{~ c m}$ & $\mathbf{8 0} \mathbf{~ c m}$ & $\mathbf{1 2 0} \mathbf{~ c m}$ & $\mathbf{1 6 0} \mathbf{~ c m}$ \\
\hline Spring & 0.22 & 0.28 & 0.24 & 0.23 & 0.31 & 0.24 \\
Summer & 0.25 & 0.31 & 0.29 & 0.30 & 0.41 & 0.33 \\
Autumn & 0.27 & 0.32 & 0.29 & 0.29 & 0.39 & 0.31 \\
Winter & 0.10 & 0.13 & 0.15 & 0.21 & 0.34 & 0.27 \\
Average & 0.21 & 0.26 & 0.24 & 0.25 & 0.36 & 0.29 \\
Range & $0.07-0.49$ & $0.09-0.45$ & $0.09-0.45$ & $0.12-0.35$ & $0.28-0.46$ & $0.23-0.43$ \\
\hline
\end{tabular}

\subsection{Seasonal Variations of Actual Evapotranspiration $\left(E T_{a}\right)$}

The seasonal variations in the $E T_{a}$ at the Yingke site from November 2007 to January 2009 are shown in Figure 6. The daily mean $E T_{a}$ was 1.49 in spring, 3.90 in summer, 1.41 in autumn and $0.22 \mathrm{~mm} \cdot$ day $^{-1}$ in winter. In 2008, the total $E T_{a}$ was $654.69 \mathrm{~mm}$, and the daily average $E T_{a}$ was 1.79 $\mathrm{mm}$. The $E T_{a}$ observed in the Zhangye oasis cornfield was higher than the $E T_{a}$ observed in an arid oasis ecosystem of the Syrian desert in Palmyra [52] and a Tamarix ramosissima ecosystem in the extremely arid region of northwestern China [21].

In 2008, the emergence time of maize occurred on 6 May, and the shooting stage of maize began on 19 June. The heading stage of maize began on 20 July. The filling stage of maize occurred from 5 August to 10 September, and the maturity stage occurred from 11 September to 22 September. The crops were harvested on 22 September at the observation field [53]. During the entire maize-growing stage (from 20 April to 22 September 2008), the total $E T_{a}$ was approximately $500 \mathrm{~mm}$ with a daily average $E T_{a}$ of $3.33 \mathrm{~mm} \cdot$ day $^{-1}$. As shown in Table 5, the total $E T_{a}$ values were $138.07 \mathrm{~mm}, 126.07 \mathrm{~mm}, 59.54 \mathrm{~mm}$, 
$145.27 \mathrm{~mm}$ and $31.42 \mathrm{~mm}$ and their corresponding daily average $E T_{a}$ values were $2.30 \mathrm{~mm} \cdot \mathrm{day}^{-1}$, $4.07 \mathrm{~mm} \cdot$ day $^{-1}, 3.72 \mathrm{~mm} \cdot$ day $^{-1}, 3.93 \mathrm{~mm} \cdot$ day $^{-1}$ and $2.62 \mathrm{~mm} \cdot$ day $^{-1}$ at the seedling, shooting, heading, filling and maturity stages, respectively. The rainfall was approximately $70 \mathrm{~mm}$, and the amount of irrigation water was approximately $510 \mathrm{~mm}$ during the entire maize-growing stage, which was similar to the water loss. In the study area, the $E T_{a}$ was primarily derived from irrigation and was greatly influenced by irrigation events. The cropland was irrigated with approximately $150 \mathrm{~mm}$ on 3 June, $120 \mathrm{~mm}$ on 25 June, $120 \mathrm{~mm}$ on $28 \mathrm{July}, 120 \mathrm{~mm}$ on 25 August, and $150 \mathrm{~mm}$ on 1 November, and the total irrigation water was approximately $660 \mathrm{~mm}$ in 2008 [54]. After the four intervals of irrigation in the maize-growing stage, the soil moisture content $(\mathrm{smc})$ at a depth of $10 \mathrm{~cm}$ depth exhibited a peak (the $s m c$ data on 25 August when the fourth irrigation in the maize-growing stage were lost), and $E T_{a}$ also increased. After irrigation on November 1, after the maize harvest, the $E T_{a}$ decreased slightly due to the small $R_{n}$, and because of the lower temperatures, the water in the soil was frozen in winter and stored for the next spring sowing.

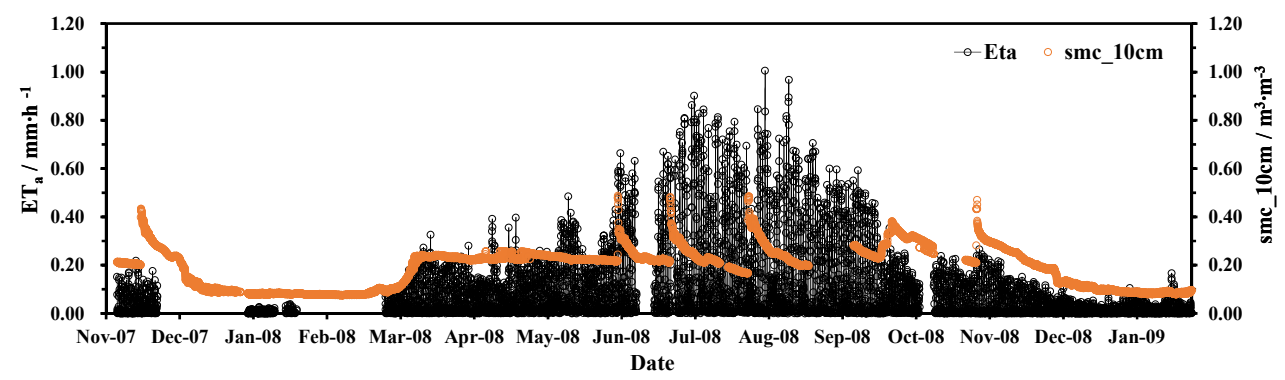

Figure 6. Hourly actual evapotranspiration $\left(E T_{a}\right)$ and soil moisture content $(\mathrm{smc})$ at 10 -cm depth at the Yingke site from November 2007 to January 2009.

Table 5. The actual evapotranspiration $\left(E T_{a}\right)$, reference evapotranspiration $\left(E T_{0}\right)$ and crop coefficient $\left(K_{c}\right)$ during different growth stages at the Yingke site in 2008.

\begin{tabular}{|c|c|c|c|c|c|c|c|}
\hline \multirow[t]{2}{*}{ Growth Stage } & \multirow{2}{*}{ Period } & \multirow[t]{2}{*}{ Days } & \multicolumn{2}{|c|}{ Cumulative $E T(\mathrm{~mm})$} & \multicolumn{2}{|c|}{$\begin{array}{c}\text { Daily Average } E T \\
\left(\mathrm{~mm} \cdot \text { Day }^{-1}\right)\end{array}$} & \multirow[t]{2}{*}{$K_{c}$} \\
\hline & & & $E t_{a}$ & $E T_{0}$ & $E t_{a}$ & $E T_{0}$ & \\
\hline Seeding stage & 20 April-18 June & 60 & 138.07 & 219.56 & 2.30 & 3.66 & 0.63 \\
\hline Shooting stage & 19 June-19 July & 31 & 126.07 & 167.97 & 4.07 & 5.42 & 0.75 \\
\hline Heading stage & 19 July-4 August & 16 & 59.54 & 76.55 & 3.72 & 4.78 & 0.78 \\
\hline Filling stage & 5 August-10 September & 37 & 145.27 & 190.08 & 3.93 & 5.14 & 0.76 \\
\hline Maturity stage & 11-22 September & 12 & 31.42 & 51.76 & 2.62 & 4.31 & 0.61 \\
\hline Whole growth stage & 20 April-22 September & 156 & 500.37 & 705.91 & 3.33 & 4.66 & 0.71 \\
\hline
\end{tabular}

During the observation period, the $E T_{a}$ increased in spring, reached a maximum in summer, decreased in autumn and then reached a minimum in winter. This phenomenon may occur because the $R_{n}$ was low in winter, and the $T_{a}$ was negative when the soil was frozen. When these conditions occurred, the soil moisture content decreased to the lowest values. The water permeability of the frozen soil layer weakened, which led to a weak relationship between the frozen soil layer and thawed soil layer, and produced low $E T_{a}$ values. Thus, the specific humidity reached a minimum. In spring, however, the $R_{n}$ was higher and the $T_{a}$ was positive when the soil thawed. Under these conditions, the soil moisture content increased, which led to increased $E T_{a}$. In summer, the growth of vegetation flourished, the $R_{n}$ reached a maximum, the wind velocity was higher, and the cornfield was irrigated four times. Under these conditions, the $E T_{a}$ and the specific humidity reached a maximum. Although the overall rainfall amount was low, the rainfall amount was greater in summer, thereby contributing to the maximum $E T_{a}$ in summer. In autumn, the $R_{n}$ and $T_{a}$ decreased, and the surface was bare without vegetation; thus, the $E T_{a}$ began to decline. 
During the observation period, the total rainfall was $117 \mathrm{~mm}$. The $E T_{a}$ values were considerably higher than the rainfall, thus leading to arid conditions. The $E T_{a}$ was greatly influenced by the irrigation events and meteorological elements. When the site was irrigated, the $E T_{a}$ peaked the following day.

A regression analysis indicated that the $E T_{a}$ is closely related to the net radiation, wind velocity, air temperature and specific humidity (Figure 7) as follows:

$$
E T_{a}\left(\mathrm{~mm} \cdot \mathrm{d}^{-1}\right)=0.22 \times R_{n}+0.25 \times W S_{2 m}+0.01 \times T_{a 2 m}+0.06 \times q_{2 m}-0.43
$$

where $R_{n}$ is the net radiation (MJ.m $\left.\mathrm{m}^{-2} \cdot \mathrm{d}^{-1}\right), W S_{2 m}$ is the wind velocity $2 \mathrm{~m}$ above the ground surface $\left(\mathrm{m} \cdot \mathrm{s}^{-1}\right), T_{a 2 m}$ is the air temperature $2 \mathrm{~m}$ above the ground surface $\left({ }^{\circ} \mathrm{C}\right)$, and $q_{2 m}$ is the specific humidity $2 \mathrm{~m}$ above the ground surface $\left(\mathrm{g} \cdot \mathrm{kg}^{-1}\right)$. The multiplex correlation coefficient was approximately 0.91 , whereas the number of cases was 313. Evapotranspiration was positively correlated with net radiation, wind velocity, air temperature and specific humidity. The regression formula (17) showed that wind velocity and net radiation play a significant role in evapotranspiration. When the relationships of evapotranspiration with meteorological factors were assessed in the upper [55] and middle [56] reaches of the Heihe River Basin, the effect of wind velocity was greatest, which is consistent with the results of this paper.

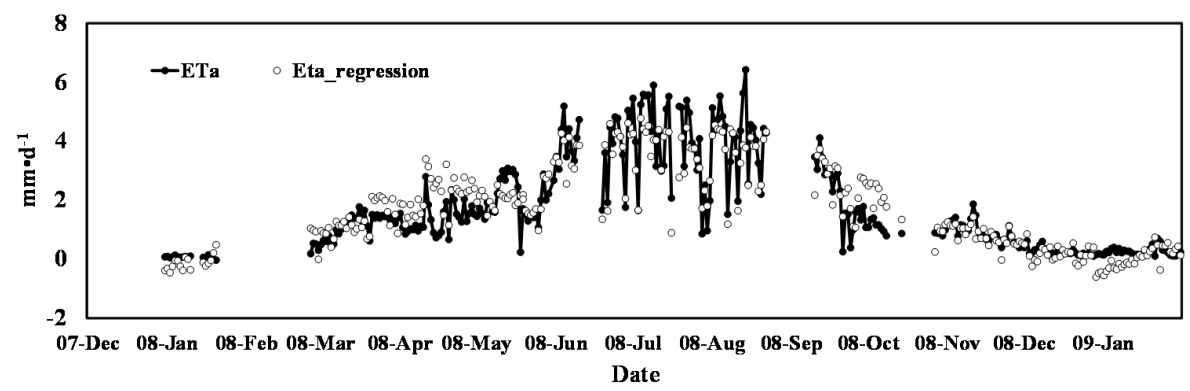

Figure 7. The comparison of the calculated results with the regression results of actual evapotranspiration $\left(E T_{a}\right)$.

\subsection{Seasonal Variations of the Reference Evapotranspiration ( $E T_{0}$ )}

The seasonal variations of the $E T_{0}$ at the Yingke site from November 2007 to January 2009 are presented in Figure 8. The daily average $E T_{0}$ values were 2.84 (spring), 5.27 (summer), 2.09 (autumn) and $0.64 \mathrm{~mm} \cdot$ day $^{-1}$ (winter). In 2008, the total $E T_{0}$ was $1039.92 \mathrm{~mm}$, and the daily average $E T_{0}$ was $2.85 \mathrm{~mm}$. The $E T_{0}$ observed in the Zhangye Oasis cornfield was similar to the values observed in a cornfield in the semiarid region of northern India [57], but was higher than the values observed in the Tanggula region of the Tibetan Plateau, except in winter [50].

During the observation period, the $E T_{0}$ was slightly higher than the $E T_{a}$, and the differences were large in summer and autumn, and small in winter and spring. Similar to the $E T_{a}$, the $E T_{0}$ increased in spring, reached a maximum in summer, decreased in autumn and reached a minimum in winter. During the entire maize-growing stage (from 20 April to 22 September 2008), the total $E T_{0}$ was approximately $706 \mathrm{~mm}$ with a daily average $E T_{0}$ of $4.53 \mathrm{~mm} \cdot$ day $^{-1}$. As shown in Table 5, the total $E T_{0}$ values were $219.56 \mathrm{~mm}, 167.97 \mathrm{~mm}, 76.55 \mathrm{~mm}, 190.08 \mathrm{~mm}$ and $51.76 \mathrm{~mm}$, and their corresponding daily average $E T_{0}$ values were $3.66 \mathrm{~mm} \cdot$ day $^{-1}, 5.42 \mathrm{~mm} \cdot$ day $^{-1}, 4.78 \mathrm{~mm} \cdot$ day $^{-1}, 5.14 \mathrm{~mm} \cdot$ day $^{-1}$ and $4.31 \mathrm{~mm} \cdot$ day $^{-1}$ at the seedling, shooting, heading, filling and maturity stages, respectively. The $E T_{0}$ was primarily impacted by meteorological elements and was not influenced by irrigation. 


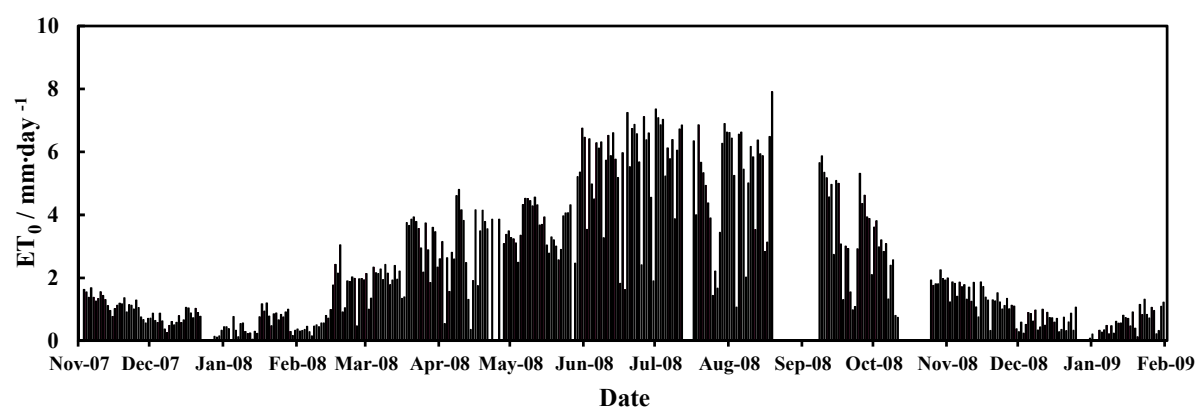

Figure 8. Daily reference evapotranspiration $\left(E T_{0}\right)$ at the Yingke site from November 2007 to January 2009.

\subsection{Crop Coefficient $\left(K_{c}\right)$}

The crop coefficient $K_{c}$ was estimated according to FAO56 [27]:

$$
K_{c}=E T_{a} / E T_{0}
$$

In 2008, the $K_{c}$ ranged from 0.31 to 0.81 (Table 6), with the maximum values occurring in July, and the minimum values occurring in January. The annual average was 0.56 , and the seasonal averages were 0.53 (spring), 0.74 (summer), 0.57 (autumn) and 0.38 (winter).

Table 6. Monthly averages of the actual evapotranspiration $\left(E T_{a}\right)$, reference evapotranspiration $\left(E T_{0}\right)$ and crop coefficient $\left(K_{c}\right)$ at the Yingke site in 2008.

\begin{tabular}{|c|c|c|c|c|c|c|c|c|c|c|c|c|}
\hline & January & Febuary & March & April & May & June & July & August & September & October & November & December \\
\hline $\begin{array}{c}E T_{a} \\
\left(\mathrm{~mm} \cdot \mathrm{day}^{-1}\right)\end{array}$ & 0.17 & 0.38 & 1.17 & 1.37 & 1.99 & 3.83 & 3.99 & 3.89 & 2.50 & 1.09 & 0.90 & 0.25 \\
\hline $\begin{array}{c}E T_{0} \\
\left(\mathrm{~mm} \cdot \mathrm{day}^{-1}\right)\end{array}$ & 0.54 & 0.95 & 2.42 & 2.55 & 3.58 & 5.49 & 4.93 & 5.40 & 3.78 & 2.47 & 1.47 & 0.57 \\
\hline$K_{c}$ & 0.31 & 0.40 & 0.48 & 0.54 & 0.56 & 0.70 & 0.81 & 0.72 & 0.66 & 0.44 & 0.61 & 0.44 \\
\hline
\end{tabular}

The $K_{c}$ values were less than 0.5 outside of the maize-growing stage, because the cornfield was bare without vegetation and not irrigated, except for several rainfall events in April and one irrigation in November.

The $K_{c}$ values were greater than 0.5 during the entire maize-growing stage (from 20 April to 22 September 2008) because the growth of corn flourished, and the cornfield was irrigated four times. As shown in Table 5, the $K_{c}$ values were $0.63,0.75,0.78,0.76,0.61$ and 0.71 at the seedling stage, shooting stage, heading stage, filling stage, maturity stage and the entire growth stage, respectively. Li et al. [25] reported that maize $K_{c}$ values in Wuwei City, Gansu Province of northwestern China, at the seedling, shooting, heading, filling, and maturity stages were $0.44,0.95,1.46,1.39$, and 1.22 , respectively, which generally were higher than our results, except at the seedling stage. The differences are mainly caused by two factors. (1) $K_{c}$ is related to vegetation coverage [27]. In the study by Li et al. [25], maize was sown with $40 \mathrm{~cm}$ row spacing and $6.7 \mathrm{~cm}$ planting spacing, and thus the planting density was higher, consisting of approximately 374,800 plants $\mathrm{ha}^{-1}$. This higher density led to a higher $K_{c}$ in the middle and late periods of the growing season. By contrast, in the present study, the maize was sown with a $60 \mathrm{~cm}$ row spacing and $25 \mathrm{~cm}$ planting spacing, resulting in a lower planting density of approximately 67,000 plants ha ${ }^{-1}$ and, consequently, a lower $K_{c}$ in the middle and late periods of the growing season. (2) The $E T_{0}$ estimated by the FAO56 model was underestimated in the middle and late maize-growing seasons in the study by Li et al. Kang et al. [58] observed a similar underestimation of $E T_{0}$ based on FAO56 in the Loess Plateau, Shaanxi, China, and a higher $K_{c}$ compared with the values given by Allen et al. [27]. This phenomenon also led to a higher $K_{c}$ in the middle and late growing seasons. 
In recent years, other methods of studying the $K_{c}$ of maize have been used, such as models and remote sensing methods. Miao et al. [59] focused on the actual evapotranspiration, crop transpiration and crop coefficient using the SIMDualKc model which is a model for simulating soil water balance based on FAO56 double crop coefficient method in the Hetao irrigation district of the upper Yellow River basin, China, and a new modelling approach was developed for the basal crop coefficients $\left(K_{c b}\right)$ of a relay-strip intercropping system. Kullberg et al. [60] compared several remote sensing methods to calculate crop evapotranspiration and $K_{c b}$ in a deficit irrigation experiment for maize near Greeley, Colorado, and the results showed that remote sensing methods can inform users about the availability of certain data and irrigation levels. Models and remote sensing methods are important methods in regional evapotranspiration and $K_{c}$ research [61-63].

\section{Conclusions}

Based on the EC system and the AWS-Tower data of the Yingke site from November 2007 to January 2009 in the Zhangye oasis cornfield of northwestern China, the characteristics of the $E T_{a}$ and $E T_{0}$ and $K_{c}$ were analysed and compared. The following conclusions have been drawn.

1. In 2008, the total $E T_{a}$ and $E T_{0}$ were $654.69 \mathrm{~mm}$ and $1039.92 \mathrm{~mm}$, respectively; the total rainfall was $117 \mathrm{~mm}$, the irrigation water was approximately $660 \mathrm{~mm}$, and these values were similar to the water loss value. The $E T_{0}$ was slightly higher than the $E T_{a}$. Differences between the two values were large in summer and autumn, and small in winter and spring. Both $E T_{a}$ and $E T_{0}$ increased in spring, reached a maximum in summer, decreased in autumn and reached a minimum in winter.

2. During the observation period, both the $E T_{a}$ and the $E T_{0}$ were substantially higher than the rainfall, which resulted in arid conditions. The $E T_{a}$ was primarily derived from irrigation and was greatly influenced by irrigation events and meteorological elements, whereas the $E T_{0}$ was not influenced by irrigation and was primarily impacted by meteorological elements.

3. In 2008, the annual average $K_{c}$ was 0.56 , and the seasonal averages were 0.53 (spring), 0.74 (summer), 0.57 (autumn) and 0.38 (winter). The $K_{c}$ values were less than 0.5 outside of the maize-growing stage, and were greater than 0.5 during the entire maize-growing stage (from 20 April to 22 September 2008). The $K_{c}$ values were $0.63,0.75,0.78,0.76,0.61$ and 0.71 at the seedling, shooting, heading, filling, and maturity stages, and the entire growth stage, respectively.

4. In 2008, the total $R_{n}$ and rainfall were $2457.73 \mathrm{MJ} \cdot \mathrm{m}^{-2}$ and $117 \mathrm{~mm}$, respectively; the average values for the wind velocity, air temperature, and specific humidity $2 \mathrm{~m}$ above the ground surface were $1.23 \mathrm{~m} \cdot \mathrm{s}^{-1}, 7.07^{\circ} \mathrm{C}$, and $3.66 \mathrm{~g} \cdot \mathrm{kg}^{-1}$, respectively. The monthly and annual averages of the wind velocity and specific humidity were lower than the average wind velocity and specific humidity observed at the Zhangye meteorological station from 1951 to 2000. Except in January, February and August in 2008, the monthly and annual average air temperature were also lower than the average air temperature from 1951 to 2000.

In this paper, we mainly studied the variation characteristics of evapotranspiration and $K_{c}$ at a single point; in the future, we hope to expand our research into the region. The $K_{c}$ research of oasis in semiarid areas is not fully understood; future research will require the application of additional methods, such as modelling or remote sensing.

Acknowledgments: This research was supported by the National Natural Science Foundation of China (41575012, $41571069,91337212,91537101)$. This data set is provided by "Heihe Plan Science Data Center, National Natural Science Foundation of China".

Author Contributions: Lianglei Gu contributed in literature search, study design, data collection, data analysis, figures, data interpretation, and article writing. Zeyong Hu contributed in study design and data collection. Jimin Yao contributed in literature search, data interpretation, and article writing. Genhou Sun contributed in data analysis and figures.

Conflicts of Interest: The authors declare no conflict of interest. 


\section{References}

1. Brutsaert, W. Evaporation into the Atmosphere: Theory, History, and Applications; D. Reidel Publishing Company: Dordrecht, The Netherlands, 1982; p. 299.

2. Jiang, L.; Islam, S.; Guo, W.; Jutla, A.S.; Senarath, S.U.; Ramsay, B.H.; Eltahir, E. A satellite-based daily actual evapotranspiration estimation algorithm over South Florida. Glob. Planet. Chang. 2009, 67, 62-77. [CrossRef]

3. Kool, D.; Agam, N.; Lazarovitch, N.; Heitman, J.; Sauer, T.; Ben-Gal, A. A review of approaches for evapotranspiration partitioning. Agric. For. Meteorol. 2014, 184, 56-70. [CrossRef]

4. Shukla, J.; Mintz, Y. Influence of land-surface evapotranspiration on the earth's climate. Science 1982, 215, 1498-1501. [CrossRef] [PubMed]

5. Sun, L.; Wu, G. Influence of land evapotranspiration on climate variations. Sci. China Ser. Earth Sci. 2001, 44, 838-846. [CrossRef]

6. Wang, K.; Dickinson, R.E. A review of global terrestrial evapotranspiration: Observation, modeling, climatology, and climatic variability. Rev. Geophys. 2012, 50. [CrossRef]

7. Deo, R.C.; Şahin, M. Application of the artificial neural network model for prediction of monthly standardized precipitation and evapotranspiration index using hydrometeorological parameters and climate indices in Eastern Australia. Atmos. Res. 2015, 161, 65-81. [CrossRef]

8. Chahine, M.T. The hydrological cycle and its influence on climate. Nature 1992, 359, 373-380. [CrossRef]

9. Chen, S.B.; Liu, Y.F.; Thomas, A. Climatic change on the Tibetan plateau: Potential evapotranspiration trends from 1961-2000. Clim. Chang. 2006, 76, 291-319. [CrossRef]

10. Giambelluca, T.W.; Martin, R.E.; Asner, G.P.; Huang, M.; Mudd, R.G.; Nullet, M.A.; DeLay, J.K.; Foote, D. Evapotranspiration and energy balance of native wet montane cloud forest in Hawai'i. Agric. For. Meteorol. 2009, 149, 230-243. [CrossRef]

11. Ma, W.; Ma, Y.; Ishikawa, H. Evaluation of the SEBS for upscaling the evapotranspiration based on in-situ observations over the Tibetan plateau. Atmos. Res. 2014, 138, 91-97. [CrossRef]

12. Webster, P.J. Mechanisms of monsoon low-frequency variability: Surface hydrological effects. J. Atmos. Sci. 1983, 40, 2110-2124. [CrossRef]

13. Bolle, H.J.; Andre, J.C.; Arrue, J.; Barth, H.; Bessemoulin, P.; Brasa, A.; de Bruin, H.; Cruces, J.; Dugdale, G.; Engman, E. EFEDA: European field experiment in a desertification-threatened area. Ann. Geophys. 1993, 11, 173-189.

14. Goutorbe, J.P.; Lebel, T.; Tinga, A.; Bessemoulin, P.; Brouwer, J.; Dolman, A.J.; Engman, E.T.; Gash, J.H.C.; Hoepffner, M.; Kabat, P.; et al. HAPEX-Sahel: A large-scale study of land-atmosphere interactions in the semi-arid tropics. Ann. Geophys. 1994, 12, 53-64. [CrossRef]

15. Hu, Y.; Gao, Y.; Wang, J.; Ji, G.; Shen, Z.; Cheng, L.; Chen, J.; Li, S. Some achievements in scientific research during HEIFE. Plateau Meteorol. 1994, 13, 225-236.

16. Wang, J. Land surface process experiments and interaction study in China: From HEIFE to IMGRASS and GAME-Tibet/TIPEX. Plateau Meteorol. 1999, 18, 280-294.

17. Daren, L.; Zuozhong, C.; Jiayi, C.; Hongbin, C.; Gengchen, W.; Jinjun, J.; Zhongling, L. Study on soil-vegetation-atmosphere interaction in Inner-Mongolia semi-arid grassland. Acta Meteorol. Sin. 2005, 63, 571-593.

18. Zhang, Q.; Huang, R.; Wang, S. NWC-ALIEX and its research advances. Adv. Earth Sci. 2005, 20, 427-441.

19. Ji, X.B.; Kang, E.S.; Chen, R.S.; Zhao, W.Z.; Xiao, S.C.; Jin, B.W. Analysis of water resources supply and demand and security of water resources development in irrigation regions of the middle reaches of the Heihe River Basin, Northwest China. Agric. Sci. China 2006, 5, 130-140. [CrossRef]

20. Kang, E.; Cheng, G.; Song, K.; Jin, B.; Liu, X.; Wang, J. Simulation of energy and water balance in soil-vegetation-atmosphere transfer system in the mountain area of Heihe River Basin at Hexi corridor of Northwest China. Sci. China Ser. Earth Sci. 2005, 48, 538-548. [CrossRef]

21. Si, J.; Feng, Q.; Zhang, X.; Liu, W.; Su, Y.; Zhang, Y. Growing season evapotranspiration from Tamarix ramosissima stands under extreme arid conditions in Northwest China. Environ. Geol. 2005, 48, 861-870. [CrossRef]

22. Tong, L.; Kang, S.; Zhang, L. Temporal and spatial variations of evapotranspiration for spring wheat in the Shiyang River Basin in Northwest China. Agric. Water Manag. 2007, 87, 241-250. [CrossRef] 
23. Zhao, C.; Nan, Z.; Cheng, G. Methods for estimating irrigation needs of spring wheat in the middle Heihe Basin, China. Agric. Water Manag. 2005, 75, 54-70. [CrossRef]

24. Li, X.; Li, X.; Li, Z.; Ma, M.; Wang, J.; Xiao, Q.; Liu, Q.; Che, T.; Chen, E.; Yan, G.; et al. Watershed allied telemetry experimental research. J. Geophys. Res. Atmos. 2009, 114. [CrossRef]

25. Li, S.; Kang, S.; Li, F.; Zhang, L. Evapotranspiration and crop coefficient of spring maize with plastic mulch using eddy covariance in Northwest China. Agric. Water Manag. 2008, 95, 1214-1222. [CrossRef]

26. Ma, G.X.; Gan, G.H.; Tian, Y.J. Development models of Zhangye oasis cities and towns under restraint of water resources. J. Desert Res. 2006, 26, 426-431.

27. Allen, R.G.; Pereira, L.S.; Raes, D. Crop Evapotranspiration: Guidelines for Computing Crop Requirements. Irrigation and Drainage Paper no. 56; FAO: Rome, Italy, 1998; p. 300.

28. Utset, A.; Farre, I.; Martinez-Cob, A.; Cavero, J. Comparing Penman-Monteith and Priestley-Taylor approaches as reference-evapotranspiration inputs for modeling maize water-use under mediterranean conditions. Agric. Water Manag. 2004, 66, 205-219. [CrossRef]

29. Li, S.; Zhao, W. Satellite-based actual evapotranspiration estimation in the middle reach of the Heihe River Basin using the Sebal method. Hydrol. Process. 2010, 24, 3337-3344. [CrossRef]

30. Guyot, A.; Cohard, J.M.; Anquetin, S.; Galle, S.; Lloyd, C.R. Combined analysis of energy and water balances to estimate latent heat flux of a Sudanian small catchment. J. Hydrol. 2009, 375, 227-240. [CrossRef]

31. Cai, J.; Liu, Y.; Lei, T.; Pereira, L.S. Estimating reference evapotranspiration with the FAO Penman-Monteith equation using daily weather forecast messages. Agric. For. Meteorol. 2007, 145, 22-35. [CrossRef]

32. Dai, X.; Shi, H.; Li, Y.; Ouyang, Z.; Huo, Z. Artificial neural network models for estimating regional reference evapotranspiration based on climate factors. Hydrol. Process. 2009, 23, 442-450. [CrossRef]

33. Lecina, S.; Martınez-Cob, A.; Pérez, P.; Villalobos, F.; Baselga, J. Fixed versus variable bulk canopy resistance for reference evapotranspiration estimation using the Penman-Monteith equation under semiarid conditions. Agric. Water Manag. 2003, 60, 181-198. [CrossRef]

34. Pauwels, V.R.N.; Samson, R. Comparison of different methods to measure and model actual evapotranspiration rates for a wet sloping grassland. Agric. Water Manag. 2006, 82, 1-24. [CrossRef]

35. Prueger, J.H.; Kustas, W.P.; Hipps, L.E.; Hatfield, J.L. Aerodynamic parameters and sensible heat flux estimates for a semi-arid ecosystem. J. Arid Environ. 2004, 57, 87-100. [CrossRef]

36. Kalthoff, N.; Fiebig-Wittmaack, M.; Meißner, C.; Kohler, M.; Uriarte, M.; Bischoff-Gauß, I.; Gonzales, E. The energy balance, evapo-transpiration and nocturnal dew deposition of an arid valley in the Andes. J. Arid. Environ. 2006, 65, 420-443. [CrossRef]

37. Wilczak, J.M.; Oncley, S.P.; Stage, S.A. Sonic anemometer tilt correction algorithms. Bound. Layer Meteorol. 2001, 99, 127-150. [CrossRef]

38. Leuning, R.; Cleugh, H.A.; Zegelin, S.J.; Hughes, D. Carbon and water fluxes over a temperate eucalyptus forest and a tropical wet/dry savanna in Australia: Measurements and comparison with modis remote sensing estimates. Agric. For. Meteorol. 2005, 129, 151-173. [CrossRef]

39. Scott, R.L. Using watershed water balance to evaluate the accuracy of eddy covariance evaporation measurements for three semiarid ecosystems. Agric. For. Meteorol. 2010, 150, 219-225. [CrossRef]

40. Stannard, D.I.; Blanford, J.H.; Kustas, W.P.; Nichols, W.D.; Amer, S.A.; Schmugge, T.J.; Weltz, M.A. Interpretation of surface flux measurements in heterogeneous terrain during the Monsoon ' 90 experiment. Water Resour. Res. 1994, 30, 1227-1239. [CrossRef]

41. Wang, J.; Wang, W.; Liu, S.; Ma, M.; Li, X. The Problems of Surface Energy Balance Closure-An Overview and Case Study. Adv. Earth Sci. 2009, 24, 705-714. [CrossRef]

42. Oke, T.R. Boundary Layer Climatology, 2nd ed.; Methuen: New York, NY, USA, 1987; p. 435.

43. Malek, E. Comparison of the Bowen ratio-energy balance and stability-corrected aerodynamic methods for measurement of evapotranspiration. Theor. Appl. Climatol. 1993, 48, 167-178. [CrossRef]

44. Monteith, J.L.; Unsworth, M.H. Principles of Environmental Physics; Routledge, Chapman and Hall Publishing House: New York, NY, USA, 1990; p. 228.

45. Allen, R.G.; Clemmens, A.J.; Burt, C.M.; Solomon, K.; O’Halloran, T. Prediction accuracy for projectwide evapotranspiration using crop coefficients and reference evapotranspiration. J. Irrig. Drain. Eng. 2005, 131, 24-36. [CrossRef] 
46. Allen, R.G.; Pruitt, W.O.; Wright, J.L.; Howell, T.A.; Ventura, F.; Snyder, R.; Itenfisu, D.; Steduto, P.; Berengena, J.; Yrisarry, J.B. A recommendation on standardized surface resistance for hourly calculation of reference ETo by the FAO56 Penman-Monteith method. Agric. Water Manag. 2006, 81, 1-22. [CrossRef]

47. Garcia, M.; Raes, D.; Allen, R.; Herbas, C. Dynamics of reference evapotranspiration in the Bolivian highlands (Altiplano). Agric. For. Meteorol. 2004, 125, 67-82. [CrossRef]

48. Jacobs, J.M.; Satti, S.R. Evaluation of Reference Evapotranspiration Methodologies and AFSIRS Crop Water Use Simulation Model: Final Technical Report; St. Johns River Water Management District: Palatka, FL, USA, 2001; p. 114.

49. Temesgen, B.; Eching, S.; Davidoff, B.; Frame, K. Comparison of some reference evapotranspiration equations for California. J. Irrig. Drain. Eng. 2005, 131, 73-84. [CrossRef]

50. Yao, J.; Zhao, L.; Ding, Y.; Gu, L.; Jiao, K.; Qiao, Y.; Wang, Y. The surface energy budget and evapotranspiration in the Tanggula region on the Tibetan Plateau. Cold Reg. Sci. Technol. 2008, 52, 326-340. [CrossRef]

51. Wang, J.; Mitsuta, Y. An observational study of turbulent structure and transfer characteristics in Heihe oasis. J. Meteorol. Soc. Japan 1992, 70, 1147-1154. [CrossRef]

52. Brunel, J.P.; Ihab, J.; Droubi, A.M.; Samaan, S. Energy budget and actual evapotranspiration of an arid oasis ecosystem: Palmyra (Syria). Agric. Water Manag. 2006, 84, 213-220. [CrossRef]

53. Ge, Y.; Zhuang, J.; Ma, C.; Xu, F. HiWATER: Dataset of investigation on crop phrenology and field management in the middle reaches of the Heihe river basin. Chin. Acad. Sci. 2012. [CrossRef]

54. Ge, Y.; Xu, F.; Zhuang, J. HiWATER: Dataset of investigation on channel flow and socio-economy in the middle reaches of the Heihe river basin. Chin. Acad. Sci. 2012. [CrossRef]

55. Gao, Y.; Zhao, C.; Ma, W.; Wang, Q.; Yuan, Y.; Gao, C. Evapotranspiration feature of the grassland and pan coefficient in Tianlaochi catchment in the upper reaches of Heihe River. Ecol. Sci. 2017, 36, 72-79. [CrossRef]

56. Han, S.; Liu, Q.; Yang, S. Differences of changes in potential evapotranspiration and its factors over the upper, middle and lower reaches of Heihe River Basin. Eng. J. Wuhan Univ. 2009, 42, 734-737.

57. Tyagi, N.K.; Sharma, D.K.; Luthra, S.K. Determination of evapotranspiration for maize and berseem clover. Irrig. Sci. 2003, 21, 173-181. [CrossRef]

58. Kang, S.; Gu, B.; Du, T.; Zhang, J. Crop coefficient and ratio of transpiration to evapotranspiration of winter wheat and maize in a semi-humid region. Agric. Water Manag. 2003, 59, 239-254. [CrossRef]

59. Miao, Q.; Rosa, R.D.; Shi, H.; Paredes, P.; Zhu, L.; Dai, J.; Goncalves, J.M.; Pereira, L.S. Modeling water use, transpiration and soil evaporation of spring wheat-maize and spring wheat-sunflower relay intercropping using the dual crop coefficient approach. Agric. Water Manag. 2016, 165, 211-229. [CrossRef]

60. Kullberg, E.G.; DeJonge, K.C.; Chávez, J.L. Evaluation of thermal remote sensing indices to estimate crop evapotranspiration coefficients. Agric. Water Manag. 2017, 179, 64-73. [CrossRef]

61. Singh, R.K.; Senay, G.B. Comparison of Four Different Energy Balance Models for Estimating Evapotranspiration in the Midwestern United States. Water 2016, 8, 9. [CrossRef]

62. Cornelissen, T.; Diekkrüger, B.; Bogena, H.R. Using High-Resolution Data to Test Parameter Sensitivity of the Distributed Hydrological Model HydroGeoSphere. Water 2016, 8, 202. [CrossRef]

63. Zhuang, Q.; Wu, B. Estimating Evapotranspiration from an Improved Two-Source Energy Balance Model Using ASTER Satellite Imagery. Water 2015, 7, 6673-6688. [CrossRef]

(C) 2017 by the authors. Licensee MDPI, Basel, Switzerland. This article is an open access article distributed under the terms and conditions of the Creative Commons Attribution (CC BY) license (http://creativecommons.org/licenses/by/4.0/). 